\title{
Frequency of Variants in DNA-Repair Genes in a Southwest Colombian Population
}

\section{Frecuencia de las variantes en genes de reparación del ADN en una población del suroccidente de Colombia}

\author{
Herney Andrés García-Perdomo ${ }^{1,2}$ Mailyn Alejandra Bedoya Saldarriaga ${ }^{3} \quad$ Adalberto Sánchez $^{1,3}$ \\ Address for correspondence Herney Andrés García-Perdomo, MD, \\ MSc, EdD, PhD, FACS, Universidad del Valle, Cll 4B \# 36-00, Cali, Valle \\ del Cauca, Colombia (e-mail: Herney.garcia@correounivalle.edu.co).
}

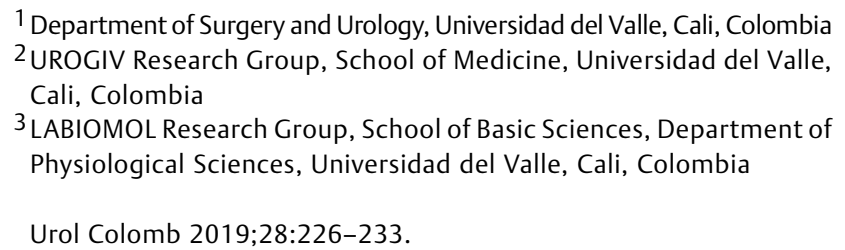

\begin{abstract}
Keywords

- gene

- prostate neoplasm

- DNA

- population

- polymorphism
\end{abstract}

\section{Resumen}

Objective To describe the frequency of mutations in DNA-repair genes in a southwestern Colombian population.

Methods We have designed an observational study, including 162 people from all ages from southwest Colombia. We have extracted and collected their DNA in filters. We have immersed the DNA in a phosphate buffer along with DNeasy package (Thermo Fisher Scientific, Waltham, MA, USA). The preparation process was with the TruSeq Exome Library Prep (Illumina, Inc. San Diego, CA, USA), then the obtained libraries were normalized with TruSeq Rapid Exome (Illumina, Inc. San Diego, CA, USA). We sequenced the full exome and identified the variants associated with 12 genes (ataxia telangiectasia mutated [ATM], BRCA1 DNA repair associated [BRCA1], BRCA2 DNA repair associated [BRCA2], checkpoint kinase 2 [CHEK2], epithelial cell adhesion molecule [EPCAM], homeobox protein Hox-B13 [HOXB13], mutS homolog 1, 2 and 6 [MLH1, MSH2, MSH6], nibrin [NBN], PMS1 homolog 2, mismatch repair system component [PMS2], and tumor protein p53 [TP53]). Descriptive statistics were performed with the $R$ software (The $R$ Foundation for Statistical Computing, Vienna, Austria).

Results A total of 7,315,466 pieces of data were sequenced in this population. The most frequently mutated genes were ATM (1,221 pieces of data; $13.2 \%), B R C A 1$ (1,178 pieces of data; $12.8 \%$ ), BRCA2 (1,484 pieces of data; $16.12 \%$ ), and NBN (965 pieces of data; $10.42 \%$ ). The most common single nucleotide polymorphisms (SNPs) in these 12 genes were the following: BRCA2 (rs169547, rs206075, rs206076); ATM (rs659243, rs228589); TP53 (rs1625895, rs1042522, rs1642785); PMS2 (rs2228006, rs1805319); NBN (rs709816); and MSH6 (rs3136367)

Conclusion The BRCA2, ATM, BRCA1 and NBN DNA-repair genes were the most frequently mutated in this southwestern Colombian Population.

Objetivo Describir la frecuencia de las mutaciones en los genes de reparación del ADN en una población del suroccidente de Colombia. received

December 27, 2018

accepted

April 2, 2019
DOI https://doi.org/ $10.1055 / \mathrm{s}-0039-1688964$. ISSN 0120-789X. eISSN 2027-0119.
Copyright (c) 2019, Sociedad Colombiana License terms de Urología. Publicado por Thieme Revinter Publicações Ltda., Rio de Janeiro, Brazil. Todos los derechos reservados.

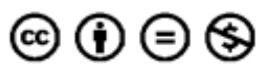




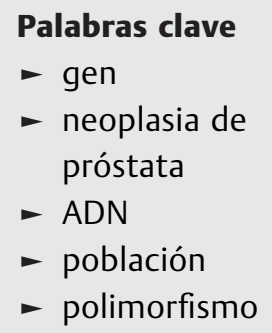

Métodos Diseñamos un estudio observacional que incluyó a 162 personas del suroccidente de Colombia de todas las edades. Hemos extraído y recogido el ADN en filtros. Los sumergimos en tampón fosfato junto con el paquete DNeasy (Thermo Fisher Scientific, Waltham, MA, EEUU). El proceso de preparación fue realizado con TruSeq Exome Library Prep (Illumina, Inc. San Diego, CA, EEUU); luego, las bibliotecas obtenidas se normalizaron con TruSeq Rapid Exome (Illumina, Inc. San Diego, CA, USA). Secuenciamos el exoma completo e identificamos las variantes asociadas a doce genes (ataxia telangiectasia mutated [ATM], BRCA1 DNA repair associated [BRCA1], BRCA2 DNA repair associated [BRCA2], checkpoint kinase 2 [CHEK2], epithelial cell adhesion molecule [EPCAM], homeobox protein Hox-B13 [HOXB13], mutS homolog 1, 2 and 6 [MLH1, MSH2, MSH6], nibrin [NBN], PMS1 homolog 2, mismatch repair system component [PMS2], y tumor protein p53 [TP53]). La estadística descriptiva se realizó en el programa R (The R Foundation for Statistical Computing, Viena, Austria).

Resultados Un total de 7.315.466 datos fueron secuenciados en esta población. Los genes más frecuentemente mutados fueron el ATM, con 1.221 datos (13,2\%), el BRCA1, con 1.178 datos (12,8\%), el BRCA2, con 1.484 datos $(16,12 \%)$ y el NBN, con 965 datos (10,42\%). Los polimorfismos de un solo nucleótido (PSN) más comunes en estos 12 genes fueron los siguientes: BRCA2 (rs169547, rs206075, rs206076); ATM (rs659243, rs228589); TP53 (rs1625895, rs1042522, rs1642785); PMS2 (rs2228006, rs1805319); NBN (rs709816) y MSH6 (rs3136367)

Conclusión Los genes de reparación de ADN BRCA2, ATM, BRCA1 NBN fueron los más frecuentemente mutados en esta población del suroccidente de Colombia.

\section{Introduction}

Prostate cancer (PCa) is the most frequent malignant neoplasia diagnosed in men, considering developing countries and the developed ones (excluding skin cancer); besides, it is one of the main causes of death. ${ }^{1-3}$ This condition has a high incidence and prevalence; however, it is possible to find a substantial variation according to the geographic location and to some ethnic groups; ${ }^{4}$ for example: in Asian countries like China, PCa has a lower incidence, while in North America, especially in Afro-American individuals, the incidence is higher. ${ }^{5-7}$ Additionally, having a first-grade relative with PCa, the risk is increased by two, and with two relatives, the risk increases five times (OR 2 years 5 respectively). ${ }^{8}$

Another important factor is the general classification as sporadic versus familiar $\mathrm{PCa},{ }^{6}$ being the latter the most frequently associated with the onset of the disease at early ages ( $\sim 45$ years old) in members from the same family. Familiar Pca has been reported as frequent as $15 \%$, while in sporadic PCa, the genetic material is damaged by environmental exposition to different factors during the lifetime (epigenetics), and its prevalence could be as high as between 80 and $90 \%{ }^{6,9}$ Prostate cancer is known as one of the most inherited cancers around the world (almost 50\%); accordingly, it increases the autosomal dominant cancer predisposition. ${ }^{10,11}$

Mutations in DNA-repair genes such as BRCA2 DNA repair associated (BRCA2), BRCA1 DNA repair associated (BRCA1), checkpoint kinase 2 [CHEK2], homeobox protein Hox-B13 (HOXB13), nibrin (NBN), and a series of single nucleotide polymorphisms (SNPs) ${ }^{8}$ have been linked to PCa and have been used as biomarkers for PCa to predict clinical outcomes in a population. ${ }^{8,12-14}$ According to this intention, research- ers need to continue studying genomic variants in different populations due to the pathological and genomic diversity.

Until now, there are no studies about genomic diversity regarding the risk for this inherited condition in a southwestern Colombian population (Nariño, Cauca, Putumayo, and Valle - which corresponds to $18 \%$ of the Colombian population). To consolidate the knowledge about this clinical condition, we need to translate information about mutations from similar predisposing populations to germline cancers to serve as sentinels to identify families with a high risk of developing this condition. The previous could serve to enable an early diagnosis in order to perform an intervention according to the individual genotype, which nowadays focuses on personalized medicine as a standard way to diagnose and to treat.

The objective of the present study was to describe the frequency of mutations in DNA-repair genes in a southwestern Colombian population.

\section{Methods}

We have designed an observational descriptive design that took place from 2014 to 2016. We have included people located in Southwest Colombia (Nariño, Cauca, Putumayo, and Valle) from all ages, multiracial, and coming from the public and private health systems. We have only excluded patients with cancer.

\section{Sample Size}

According to the expected frequency for hereditary PCa ( $\sim 15 \%)$, alfa $5 \%$ and an expected error of $5 \%$, the calculated sample size was 162 people, and the sample selection was by convenience. 


\section{DNA Extraction}

Each patient underwent blood extraction to obtain the DNA. All of the drops were collected in filter paper until they dried. These filters were immersed in phosphate buffer along with the DNeasy package (Thermo Fisher Scientific, Waltham, MA, USA). Each extraction was quantified and quality-verified to continue the sequencing processing.

\section{Sequencing Protocol}

The DNA aliquots from each sample underwent a preparation process with the TruSeq Exome Library Prep (Illumina, Inc. San Diego, CA, USA), then the obtained libraries were normalized to be sequenced using the TruSeq Rapid Exome (Illumina, Inc. San Diego, CA, USA). The normalized fragments with their corresponding adaptors for sequencing were charged in the HiSeq2500 system (Illumina, Inc. San Diego, CA, USA).

We sequenced the full exome and identified the associated variants, specifically the SNPs for 12 genes that have been associated with PCa (ataxia telangiectasia mutated [ATM], $B R C A 1, B R C A 2$, checkpoint kinase 2 [CHEK2], epithelial cell adhesion molecule [EPCAM], HOXB13, mutS homolog 1, 2 and 6 [MLH1, MSH2, MSH6], NBN, PMS1 homolog 2, mismatch repair system component [PMS2], and tumor protein p53 [TP53]). ${ }^{15}$

The present project accomplished all of the ethical international standards. Descriptive statistics were performed with the R software (The R Foundation for Statistical Computing, Vienna, Austria), ${ }^{16}$ and the results are shown in frequency tables for each gene and its associated variants. We finally searched the variants in the following public databases: Exome Aggregation Consortium (ExAC), ${ }^{17}$ PharmGKB, ${ }^{18}$ Clinvar, $^{19}$ and Ensemble, ${ }^{20}$ to look for some pattern to use the variants we found as markers.
Table 1 Frequency of variants associated with prostate cancer.

\begin{tabular}{|l|l|l|}
\hline VARIANT & $\begin{array}{l}\text { Absolute } \\
\text { frequency }\end{array}$ & $\begin{array}{l}\text { Relative } \\
\text { frequency (\%) }\end{array}$ \\
\hline Downstream & 769 & 8.347 \\
\hline Frameshift & 5 & 0.054 \\
\hline Intron & 3906 & 42.397 \\
\hline Missense & 2043 & 22.175 \\
\hline Nc_transcript & 15 & 0.163 \\
\hline Splice & 4 & 0.043 \\
\hline Stop & 12 & 0.13 \\
\hline Synonymous & 1727 & 18.745 \\
\hline Upstream & 479 & 5.199 \\
\hline UTR & 253 & 2.746 \\
\hline
\end{tabular}

Abbreviations: Nc, Non-coding; UTR, Untranslated region.

\section{Results}

\section{The Frequency of Mutated Genes}

We obtained samples from 162 people from Southwest Colombia (aged between 18 and 65 years old). A total of $7,315,466$ data were sequenced in this population. The most frequently mutated genes were ATM (1221 data; 13.2\%), BRCA1 (1178 data; 12.8\%), BRCA2 (1484 data; 16.12\%), and NBN 965 data (10.42\%) [ - Fig. 1].

\section{Associated Variants}

The missense and stop variants associated with these 12 genes were present in 22\% (2043 data) and in 0.13\% (12 data), respectively [-Table 1]. On the other hand, the ATM, BRCA1, $B R C A 2$, and PSM2 genes were the most frequently associated with missense variants $(247,445,490$ and 289 data,

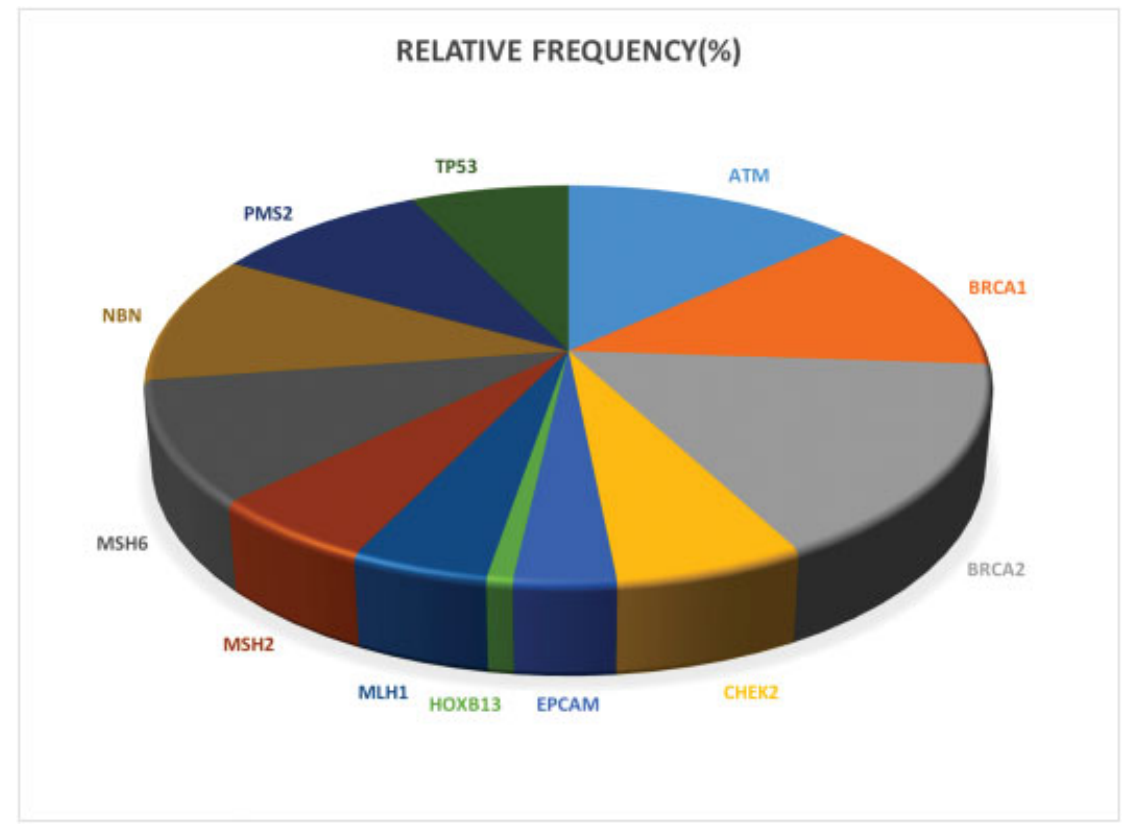

Fig. 1 Frequency of genes associated with prostate cancer. 
Table 2 Frequency of variants by each gene associated with prostate cancer

\begin{tabular}{|c|c|c|c|c|}
\hline Gene & Variant & Frequency & $\begin{array}{l}\% \text { by } \\
\text { each } \\
\text { gene }\end{array}$ & $\begin{array}{l}\% \text { by } \\
\text { total } \\
\text { variant }\end{array}$ \\
\hline \multirow[t]{2}{*}{ ATM } & Missense & 247 & 0.202 & 0.027 \\
\hline & Stop & 1 & 0.001 & 0 \\
\hline \multirow[t]{3}{*}{ BRCA1 } & Missense & 445 & 0.378 & 0.048 \\
\hline & Stop & 1 & 0.001 & 0 \\
\hline & Frameshift & 4 & 0.003 & 0 \\
\hline \multirow[t]{2}{*}{ BRCA2 } & Missense & 490 & 0.33 & 0.053 \\
\hline & Stop & 4 & 0.003 & 0 \\
\hline CHEK2 & Missense & 33 & 0.057 & 0.004 \\
\hline EPCAM & Missense & 27 & 0.088 & 0.003 \\
\hline HOXB13 & Missense & 2 & 0.025 & 0 \\
\hline \multirow[t]{2}{*}{ MLH1 } & Missense & 67 & 0.16 & 0.007 \\
\hline & Stop & 3 & 0.007 & 0.00 \\
\hline \multirow[t]{2}{*}{ MSH2 } & Missense & 13 & 0.025 & 0.001 \\
\hline & Stop & 1 & 0.002 & 0 \\
\hline \multirow[t]{2}{*}{ MSH6 } & Missense & 70 & 0.077 & 0.008 \\
\hline & Stop & 1 & 0.001 & 0 \\
\hline$N B N$ & Missense & 119 & 0.123 & 0.013 \\
\hline \multirow[t]{3}{*}{ PMS2 } & Missense & 289 & 0.323 & 0.031 \\
\hline & Stop & 1 & 0.001 & 0 \\
\hline & Frameshift & 1 & 0.001 & 0 \\
\hline TP53 & Missense & 240 & 0.365 & 0.026 \\
\hline
\end{tabular}

respectively). Additionally, the BRCA2 and $M L H 1$ genes had the highest frequency of stop variants ( 4 and 3 data, respectively) [-Table 2].

\section{Single Nucleotide Polymorphisms Associated with Prostate Cancer}

The most common SNPs in these 12 genes were the following:

BRCA2 (rs169547 [158 data; 97\%], rs206075 [158 data; 97\%], rs206076 [158 data; 97\%]); ATM (rs659243 [158 data; 97\%], rs228589 [134 data; 82\%]); TP53 (rs1625895 [157 data; 96\%], rs1042522 [141 data; 87\%], rs1642785 [145 data; 89\%]); PMS2 (rs2228006 [144 data; 88\%], rs1805319 [142 data; 87\%]); NBN (rs709816 [137 data; 84\%]), and MSH6 (rs3136367 [136 data; 83\%]) [- Table 3].

When comparing with bioinformatics databases, we found that rs169547 (BRCA2), rs 9534262 (BRCA2), rs659243 (ATM), rs228589 (ATM), rs1042522 (TP53), and rs2228006 (PMS2) had the higher Latino allele frequency found in ExAC. Additionally, rs1042522 (minor allele frequency [MAF] 0.46), rs228589 (MAF 0.46), and rs9534262 (MAF 0.47) coincided with the higher MAF found in Ensembl (https:// www.ensembl.org/index.html). Additionally, rs799917 (MAF 0.46) and rs799905 (MAF 0.45) had a high MAF, although they were not found on ExAC [ - Table 3].

\section{Discussion}

Race, diet, family history, environmental factors, and hereditary components have been reported as risk factors for PCa. ${ }^{4-7}$ Regarding the latter, genes such as BRCA1, BRCA2, MSH2, HOXB13, ATM, CHEK2, and NBN have been proposed as important candidates contributing to PCa. ${ }^{8,11-14}$ The existence of SNPs for these genes further increases the risk, and even could be used as a prognostic biomarker for this condition. ${ }^{21}$ Additionally, observing a germline mutation in some DNA-repair genes provides information to patients to look for counseling, to identify predisposition to cancer and, perhaps, to initiate interventions to reduce the risk. ${ }^{11}$

Regarding the frequency of these genes, Pritchard et al recently published a paper on patients with metastatic PCa from different series (the United Kingdom and the United States): ${ }^{11}$ however, it is important to compare some of the results: the most frequently mutated gene was BRCA2 (5.35\%) followed by CHEK2 (1.87\%), and the $3^{\text {rd }}$ was ATM(1.59\%). BRCA1 was present in $0.87 \%$ of the samples, while genes such as $M S H 2$, NBN, MSH2, MSH6, and PMS2 had a lower frequency $(0.14 \%$, $0.29 \%, 0.14 \%, 0.14 \%$, and $0.29 \%$, respectively). The HOXB13 gene was not assessed in these series. These results are lower than ours, and we might expect to have a higher frequency, coming from data from metastatic patients. The incidence of PCa, at least in Cali, Colombia, has been stable during the last few years (2002 to 2007; Annual Percent Change [APC]: 0.5\%), the mortality diminished, ${ }^{22}$ and the population of afrodescendants increased from $15 \%$ in 1964 to $26 \%$ in $2005 .{ }^{23}$ However, these data do not explain these results, since there are no previous studies that described the frequency of these genes and their variants.

Pilié et $\mathrm{al}^{24}$ published another important study to be discussed. This study was not about the frequency of genes, but it identified genes associated with PCa and other concomitant tumors (at least one additional tumor). They also found similar germline genes: BRCA2, ATM, MLH1, BRCA1, CHEK2, and HOXB13, although they found $10 \%$ of pathogenic or likely pathogenic mutations in cancer-predisposing genes. They found 525 missense, 7 frameshit, 5 in-frame coding insertion or deletions, and 2 nonsense variants (rs80359440, rs80359515, rs61757642, rs587781658, rs373226793, rs180177143, rs759113408, rs17879961, and rs138213197). In contrast, in the present study, we found a higher frequency of this type of variants and none of the SNPs they reported.

In our study, which is identified as the first study of this type in southwestern Colombia, the BRCA2 gene was the most frequently mutated, and it has been considered one of the few genes that confer a high risk of suffering from PCa and other conditions. $3,6,25,26$

The BRCA2 gene has an important role in the repair of double-strand DNA breaks, functioning by regulating the intracellular transport and the activity of RAD51, a critical protein in homologous recombination. ${ }^{27-29}$ The most frequent variants found for this gene, such as rs169547, rs206075, rs206076, and rs9534262, are similar to those found in other studies. ${ }^{30,31}$ These have been considered benign mutations ${ }^{32-34}$-the first three were reported in 


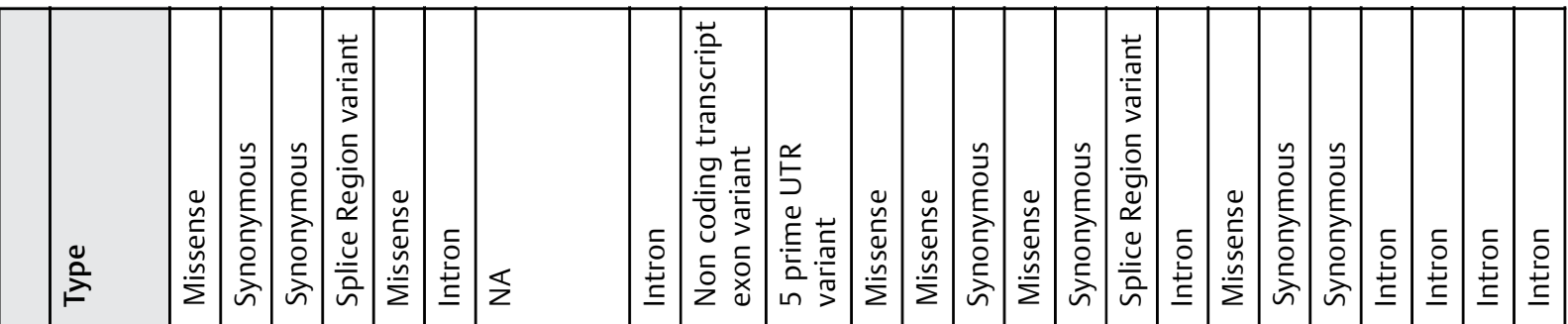

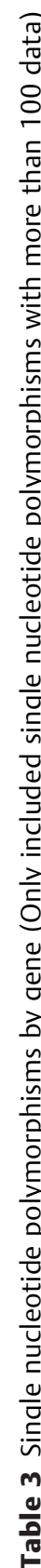<smiles>[CH-]1CC1</smiles>

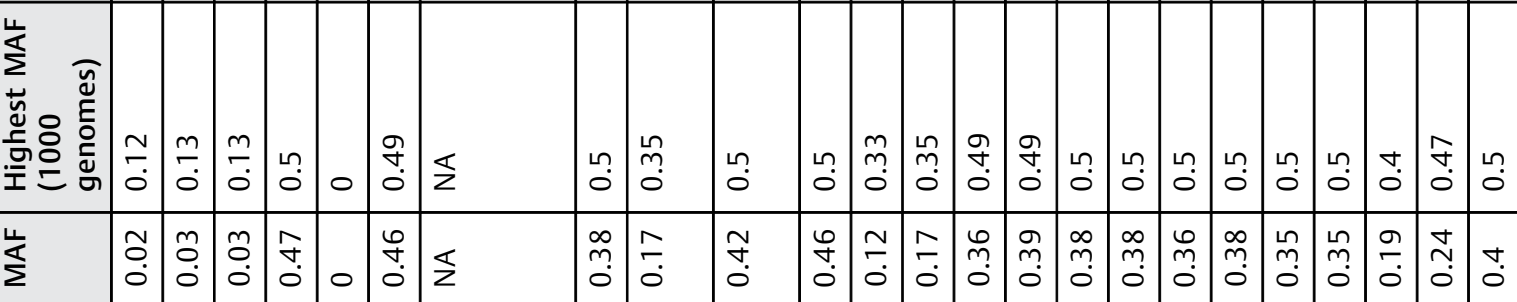

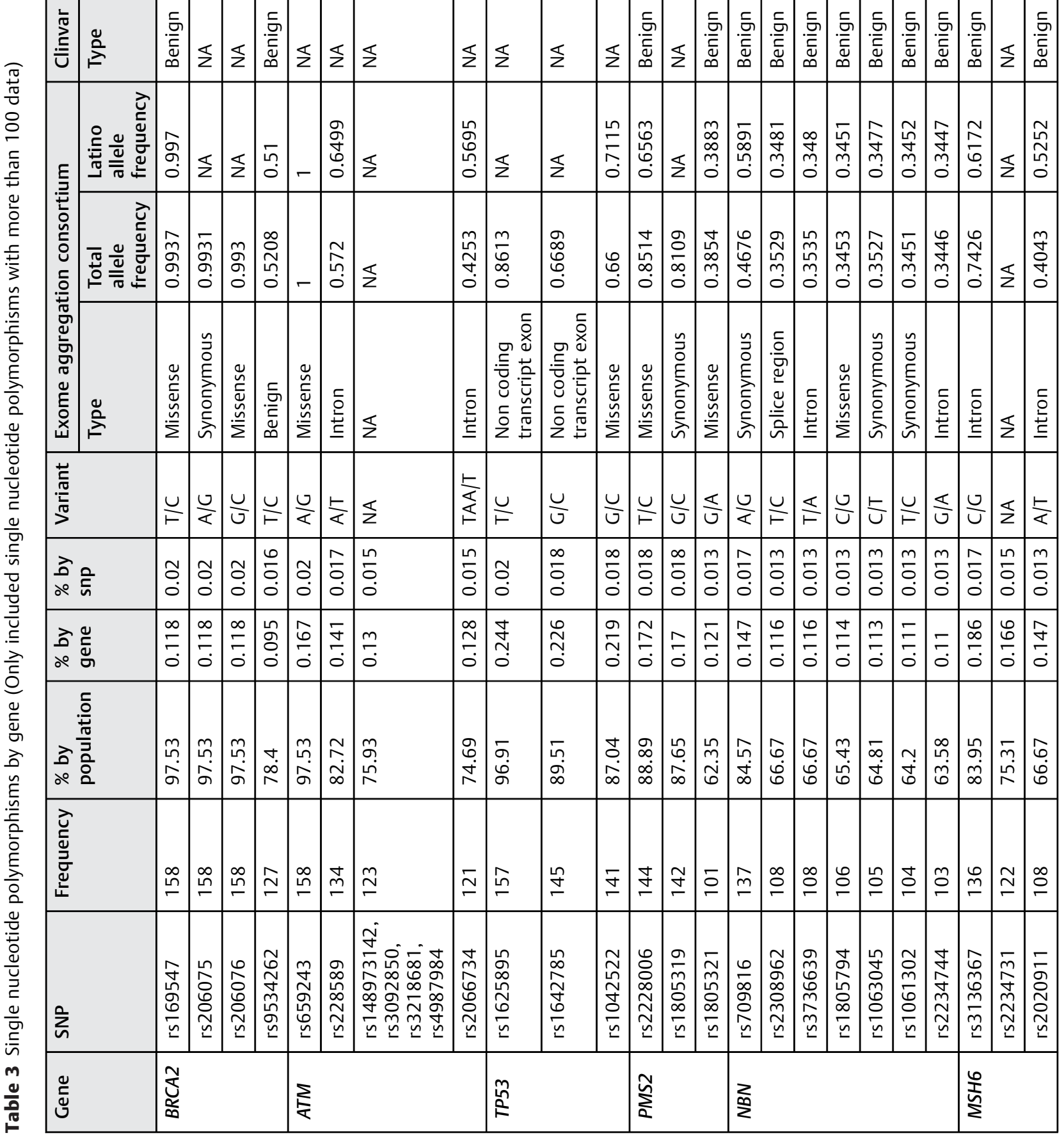




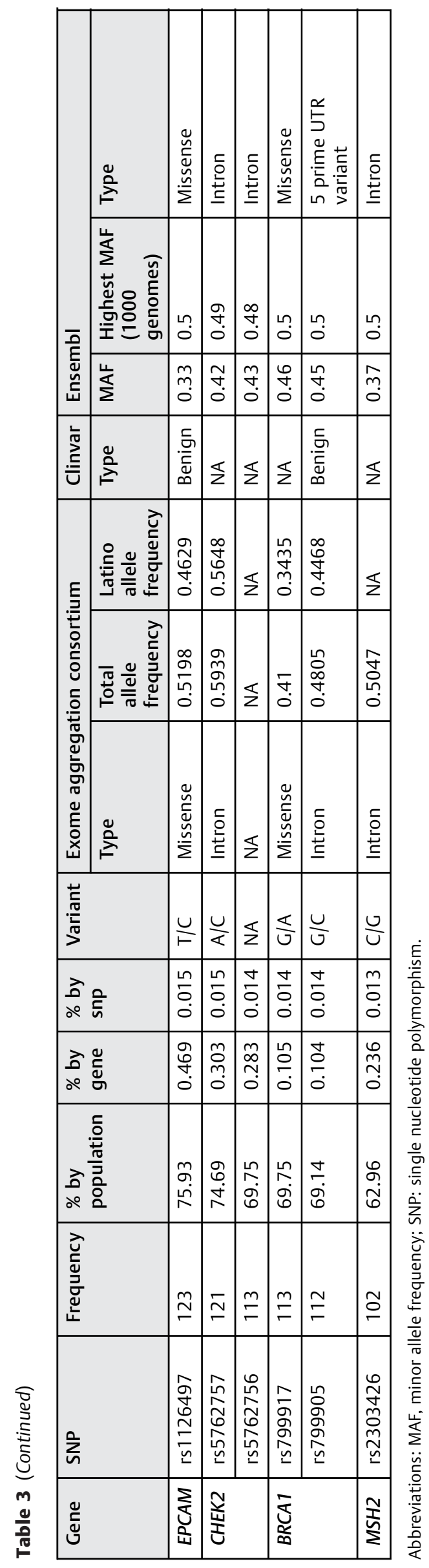

Colombia by Arias-blanco et $\mathrm{al}^{35}$-and rs9534262 was considered a deletion-type mutation with an unknown clinical relevance according to D'Argenio et $\mathrm{al}^{33}$ although it is registered as benign according to ClinVar. Rs9534262 seems to be a quantitative trait locus (QTL) of significant importance, since it regulates the levels of the alternative transcripts of the BRCA2 gene. ${ }^{36}$

The $2^{\text {nd }}$ most commonly mutated gene was ATM, which exerts control in cell division. When detecting damage in the genetic material, it leads to either cell cycle arrest, to DNA repair, or to apoptosis. ${ }^{37-39}$ In addition, it can be considered as the main transducer in the repair process of the rupture of the doublestrand, in which it recruits and cooperates with other sensor proteins, such as 53BP1 (p53 binding protein) and BRCA1.

The BRCA1 gene is the third mutated gene found and associated with an increased risk of sporadic PCa (3.5 times), while for germline mutations in this gene, while only $0.44 \%$ of PCa for germline mutations. ${ }^{5,40,41}$ The Breast Cancer Linkage Consortium (BCLC) described that men aged 65 with mutations in the BRCA1 gene report an increase in the risk of PCa with a relative risk (RR) of 1.82, being linked to a series of cellular processes such as response and repair of DNA damage, 5,39,41,42 transcriptional regulation, and chromatin modeling. This is the key in cellular control systems to be involved in all of the phases of the cycle, in such a way that it can block cell proliferation and promote the apoptosis of cells with a high risk of malignant transformation. ${ }^{5,41}$ For this gene, the most frequent variant was rs799917, a nonsense mutation-type polymorphism, ${ }^{33}$ but benign according to Arias-blanco et al. ${ }^{35}$ This one is located in the coding sequence of the gene and affects the interaction of miR-638 with the mRNA of the BRCA1 gene. ${ }^{43}$ It is also associated with the risk of suffering from breast, stomach, and esophagus cancer, additionally. ${ }^{43-45}$ These two genes have not been reported in Colombia, according to the literature review.

Another important gene found in the present study was $N B N$, which is a component of the protein complex hMRE11/ hRad50/NBN that participates in the initiation of a response to DNA damage and is linked to the repair of double-strand rupture. ${ }^{46-48}$ This acts in the nonhomologous junction pathway as a DNA damage sensor and in the homologous recombination pathway, participating in DNA repair and in the cell cycle checkpoint in the $S$ phase. ${ }^{48}$ The rs709816 polymorphism is one of its most frequent variant, which has been associated with bladder cancer ${ }^{48}$; another one was rs3736639, which has been found at a slightly higher frequency in patients with leukemia. ${ }^{46}$

On the other hand, the rs1805794 polymorphism presents positive association with different types of cancer, such as bladder, ${ }^{49,50}$ lung, ${ }^{51}$ breast, nasopharyngeal, ${ }^{52-54}$ osteosarcoma $^{55}$ and PCa. In this last one, GG carriers have an almost twice increased risk of developing PCa, suggesting a role of NBN in the diagnosis and in the progression of PCa. ${ }^{46}$ The rs1061302 polymorphism has been associated with an increased risk for lung, larynx and liver cancer. Single nucleotide polymorphisms might affect the proper binding of the complex and thus alter its ability to repair or detect DNA breaks. ${ }^{48,51}$ Although this variant is considered a synonym 
polymorphism, the altered nucleotide may affect the stability of the mRNA, the splicing, or the transduction rate. ${ }^{48}$

Additionally, rs169547 (BRCA2), rs9534262 (BRCA2), rs659243 (ATM), rs228589 (ATM), rs1042522 (TP53), and rs2228006 (PMS2) had the higher Latino allele frequency, and some of them showed coincidence with a higher MAF. This would be the first description of these kinds of SNPs for the Colombian population that leads to studying the way to work with them as a network as biomarkers for PCa.

\section{Strengths and Limitations}

This is the first study performed in the southwestern Colombian population, which is extremely important to characterize our population and to begin to recognize the risk for developing PCa. The quality of the samples, the methods we followed, and the quality and the analysis performed with the data are other important issues to highlight from our study.

Regarding the limitations, we could declare that most of the variants found in the present study are considered as benign. Nonetheless, it is important to go deeper to analyze longitudinally these data and to obtain the real risk in this population. Perhaps another important limitation could be that the extrapolation of these data is limited to people with similar characteristics in southwest Colombia.

\section{Conclusions}

To conclude, the BRCA2, ATM, BRCA1, and NBN DNA-repair genes were the most frequently mutated in this southwestern Colombian population. Additionally, there were nonpathological variants, such as rs169547, rs206075, rs206076, and rs9534262, and some other variants, such as rs799917, rs3736639, rs1061302, and rs1805794, which were associated with the NBN gene, which is highly linked to PCa.

\section{Declaration Section}

The authors declare that the present study did not receive any funding.

\section{Conflicts of Interests}

The authors have no conflicts of interests to declare.

\section{References}

1 Wu X, Gu J. Heritability of prostate cancer: a tale of rare variants and common single nucleotide polymorphisms. Ann Transl Med 2016;4(10):206

2 Packer JR, Maitland NJ. The molecular and cellular origin of human prostate cancer. Biochim Biophys Acta 2016;1863(6 Pt A):1238-1260

3 Rand KA, Rohland N, Tandon A, et al; African Ancestry Prostate Cancer GWAS Consortium; ELLIPSE/GAME-ON Consortium. Whole-exome sequencing of over 4100 men of African ancestry and prostate cancer risk. Hum Mol Genet 2016;25(02):371-381

4 Nakagawa H. Prostate cancer genomics by high-throughput technologies: genome-wide association study and sequencing analysis. Endocr Relat Cancer 2013;20(04):R171-R181

5 Castro E, Eeles R. The role of BRCA1 and BRCA2 in prostate cancer. Asian J Androl 2012;14(03):409-414

6 Alvarez-Cubero MJ, Saiz M, Martinez-Gonzalez LJ, Alvarez JC, Lorente JA, Cozar JM. Genetic analysis of the principal genes related to prostate cancer: a review. Urol Oncol 2013;31(08):1419-1429
7 Valencia O, Lopes G, Sánchez P, et al. Incidence and Prevalence of Cancer in Colombia: The Methodology Used Matters. J. Glob. Oncol. 2017;JGO.17.00008.

8 Antczak A, Wokołorczyk D, Kluźniak W, et al; Polish Hereditary Prostate Cancer Consortium. The variant allele of the rs188140481 polymorphism confers a moderate increase in the risk of prostate cancer in Polish men. Eur J Cancer Prev 2015;24 (02):122-127

9 Smith RA, Andrews KS, Brooks D, et al. Cancer screening in the United States, 2017: A review of current American Cancer Society guidelines and current issues in cancer screening. CA Cancer J Clin 2017;67(02):100-121

10 Choudhury AD, Eeles R, Freedland SJ, et al. The role of genetic markers in the management of prostate cancer. Eur Urol 2012;62 (04):577-587

11 Pritchard CC, Mateo J, Walsh MF, et al. Inherited DNA-Repair Gene Mutations in Men with Metastatic Prostate Cancer. N Engl J Med 2016;375(05):443-453

12 Seppälä EH, Ikonen T, Mononen N, et al. CHEK2 variants associate with hereditary prostate cancer. Br J Cancer 2003;89(10): 1966-1970

13 Smits M, Mehra N, Sedelaar M, Gerritsen W, Schalken JA. Molecular biomarkers to guide precision medicine in localized prostate cancer. Expert Rev Mol Diagn 2017;17(08):791-804

14 Shui IM, Lindström S, Kibel AS, et al. Prostate cancer (PCa) risk variants and risk of fatal PCa in the national cancer institute breast and prostate cancer cohort consortium. Eur Urol 2014;65(06): 1069-1075

15 GENEDx. Hereditary Prostate Cancer [Internet]. 2017 [cited May 1, 2017]. Available at: https://www.genedx.com/test-cata$\log$ /available-tests/hereditary-prostate-cancer-panel/

16 R Core Team. R: A Language and Environment for Statistical Computing. Vienna, Austria: R Foundation for Statistical Computing; 2017

17 Exome Aggregation Consortium (ExAC). ExAC Browser [Internet]. [cited Nov 11, 2017]. Available at: http://exac.broadinstitute.org/

18 Pharm GKB. PharmGKB [Internet]. [cited Nov 11, 2017]. Available at: https://www.pharmgkb.org/

19 NCBI. ClinVar [Internet]. [cited Nov 11, 2017]. Available at: https://www.ncbi.nlm.nih.gov/clinvar/

20 Ensembl. Emsembl [Internet]. [cited Nov 11, 2017]. Available at: https://www.ensembl.org/info/website/tutorials/gene_snps.html

21 Hsu FC, Sun J, Zhu Y, et al. Comparison of two methods for estimating absolute risk of prostate cancer based on single nucleotide polymorphisms and family history. Cancer Epidemiol Biomarkers Prev 2010;19(04):1083-1088

22 Restrepo JA, Bravo LE, García-Perdomo HA, García LS, Collazos P, Carbonell J. Incidencia, mortalidad y supervivencia al cáncer de próstata en Cali, Colombia, 1962-2011. Salud Publica Mex 2014; 56(05):440-447

23 Parkin D, Ferlay J, Curado M, et al. Cancer Incidence in Five Continents Volume IX Internatlonal agency for research on cancer Internatlonal assoclation of cancer regIstrles Fifty years of cancer incidence: CI5 I-IX. Int J Cancer 2010; $\cdots: 127$

24 Pilié PG, Johnson AM, Hanson KL, et al. Germline genetic variants in men with prostate cancer and one or more additional cancers. Cancer 2017;123(20):3925-3932

25 Bratt O, Loman N. Clinical Management of Prostate Cancer in Men with BRCA Mutations. Eur Urol 2015;68(02):194-195

26 Rebbeck TR. Prostate Cancer Genetics: Variation by Race, Ethnicity, and Geography. Semin Radiat Oncol 2017;27(01):3-10

27 Foulkes WD, Sugano K. BRCA2: a grown-up cancer susceptibility gene. Endocr Relat Cancer 2016;23(10):E1-E3

$28 \mathrm{Li}$ Q, Guan R, Qiao Y, et al. Association between the BRCA2 rs144848 polymorphism and cancer susceptibility: a meta-analysis. Oncotarget 2017;8(24):39818-39832

29 Na R, Zheng SL, Han M, et al. Germline Mutations in ATM and BRCA1/2 Distinguish Risk for Lethal and Indolent Prostate Cancer 
and are Associated with Early Age at Death. Eur Urol 2017;71(05): 740-747

30 Cherbal F, Salhi N, Bakour R, Adane S, Boualga K, Maillet P. BRCA1 and BRCA2 unclassified variants and missense polymorphisms in Algerian breast/ovarian cancer families. Dis Markers 2012;32 (06):343-353

31 Miao HK, Chen LP, Cai DP, Kong WJ, Xiao L, Lin J. MSH3 rs26279 polymorphism increases cancer risk: a meta-analysis. Int J Clin Exp Pathol 2015;8(09):11060-11067

32 Chen P, Zhang W, Wang X, et al. Lycopene and Risk of Prostate Cancer: A Systematic Review and Meta-Analysis. Medicine (Baltimore) 2015;94(33):e1260

33 D'Argenio V, Esposito MV, Telese A, et al. The molecular analysis of BRCA1 and BRCA2: Next-generation sequencing supersedes conventional approaches. Clin Chim Acta 2015;446:221-225

34 De Silva S, Tennekoon KH, Dissanayake A, De Silva K, Jayasekara L. Novel and reported pathogenic variants in exon 11 of BRCA2 gene in a cohort of Sri Lankan young breast cancer patients. Fam Cancer 2017;16(03):329-338

35 Arias-blanco JF, Ospino-durán EA, Restrepo-fernández CM, et al. Frequency of sequence mutations and variants for the BRCA1 and BRCA2 genes in a sample of Colombian. Rev Colomb Obstet Ginecol 2015;66:287-296

36 Ruiz de Garibay G. Síndromes Hereditarios De Cáncer De Mama Familiar: Variantes De Significado Clínico Incierto Y Consejo Genético. Universidad Complutense de Madrid; 2014

37 Cui M, Gao XS, Gu X, et al. BRCA2 mutations should be screened early and routinely as markers of poor prognosis: evidence from 8,988 patients with prostate cancer. Oncotarget 2017;8(25): 40222-40232

38 Yang H, Spitz MR, Stewart DJ, Lu C, Gorlov IP, Wu X. ATM sequence variants associate with susceptibility to non-small cell lung cancer. Int J Cancer 2007;121(10):2254-2259

39 Li D, Kumaraswamy E, Harlan-Williams LM, Jensen RA. The role of BRCA1 and BRCA2 in prostate cancer. Front Biosci 2013; 18:1445-1459

40 Choi M, Kipps T, Kurzrock R. ATM Mutations in Cancer: Therapeutic Implications. Mol Cancer Ther 2016;15(08):1781-1791

41 Cavanagh H, Rogers KMA. The role of BRCA1 and BRCA2 mutations in prostate, pancreatic and stomach cancers. Hered Cancer Clin Pract 2015;13(01):16

42 Buleje J, Guevara-Fujita M, Acosta O, et al. Mutational analysis of $B R C A 1$ and $B R C A 2$ genes in Peruvian families with hereditary breast and ovarian cancer. Mol Genet Genomic Med 2017;5(05):481-494
43 Nicoloso MS, Sun H, Spizzo R, et al. Single-nucleotide polymorphisms inside microRNA target sites influence tumor susceptibility. Cancer Res 2010;70(07):2789-2798

44 Huo X, Lu C, Huang X, et al. Polymorphisms in BRCA1, BRCA1interacting genes and susceptibility of breast cancer in Chinese women. J Cancer Res Clin Oncol 2009;135(11):1569-1575

45 Wang $\mathrm{Q}$ Lu Q, Zhao H. A review of study designs and statistical methods for genomic epidemiology studies using next generation sequencing. Front Genet 2015;6:149

46 Berardinelli F, di Masi A, Antoccia A. NBN Gene Polymorphisms and Cancer Susceptibility: A Systemic Review. Curr Genomics 2013;14(07):425-440

47 Mehdinejad M, Sobhan MR, Mazaheri M, et al. Genetic Association between ERCC2, NBN, RAD51 Gene Variants and Osteosarcoma Risk: a Systematic Review and. 2017;18:1315-1321.

48 Park SL, Bastani D, Goldstein BY, et al. Associations between NBS1 polymorphisms, haplotypes and smoking-related cancers. Carcinogenesis 2010;31(07):1264-1271

49 Vineis P, Manuguerra M, Kavvoura FK, et al. A field synopsis on low-penetrance variants in DNA repair genes and cancer susceptibility. J Natl Cancer Inst 2009;101(01):24-36

50 Lu M, Lu J, Yang X, et al. Association between the NBS1 E185Q polymorphism and cancer risk: a meta-analysis. BMC Cancer 2009;9:124

$51 \mathrm{Xu}$ J-L, Hu L-M, Huang M-D, et al. Genetic variants of NBS1 predict clinical outcome of platinum-based chemotherapy in advanced non-small cell lung cancer in Chinese. Asian Pac J Cancer Prev 2012;13(03):851-856

52 Medina PP, Ahrendt SA, Pollan M, Fernandez P, Sidransky D, Sanchez-Cespedes M. Screening of homologous recombination gene polymorphisms in lung cancer patients reveals an association of the NBS1-185Gln variant and p53 gene mutations. Cancer Epidemiol Biomarkers Prev 2003;12(08):699-704

53 Stern MC, Lin J, Figueroa JD, et al; International Consortium of Bladder Cancer. Polymorphisms in DNA repair genes, smoking, and bladder cancer risk: findings from the international consortium of bladder cancer. Cancer Res 2009;69(17):6857-6864

54 Zheng J, Zhang C, Jiang L, et al. Functional NBS1 polymorphism is associated with occurrence and advanced disease status of nasopharyngeal carcinoma. Mol Carcinog 2011;50(09):689-696

55 Jin G, Wang M, Chen W, Shi W, Yin J, Gang W. Single nucleotide polymorphisms of nucleotide excision repair and homologous recombination repair pathways and their role in the risk of osteosarcoma. Pak J Med Sci 2015;31(02):269-273 